\title{
A New Tool for Developing the Community- Engaged Scholar: Review of The Craft of Community-Engaged Teaching and Learning
}

\section{Anthony Vinciguerra}

Boston College, USA 


\title{
A New Tool for Developing the Community-Engaged Scholar: Review of The Craft of Community-Engaged Teaching and Learning
}

The Craft of Community-Engaged Teaching and Learning: A Guide for Faculty Development, by Marshall Welch and Star Plaxton-Moore. Campus Compact. 2019. ISBN: 1733902809. 240 pp.

\author{
Reviewed by Anthony Vinciguerra \\ Boston College, USA
}

\begin{abstract}
In The Craft of Community-Engaged Teaching and Learning: A Guide for Faculty Development, Marshall Welch and Star Plaxton-Moore provide an accessible, yet comprehensive, introduction to the field of community-engaged scholarship. The book's three major sections provide a developmental sequence that can help faculty establish core competencies of the community-engaged scholar. Although intended to be used as a textbook for faculty development programs, new and seasoned engaged scholars alike will benefit from this nearly encyclopedic overview of the history, theoretical foundations, and best practices of university-community engagement.
\end{abstract}

Keywords: faculty development, service-learning and community engagement, teaching and learning

Una nueva herramienta para el desarrollo el académicos comprometidos con la comunidad: Revisión de El arte de la enseñanza y el aprendizaje a través de la participación comunitaria

En El arte de la enseñanza y el aprendizaje a través de la participación comunitaria:

Una guía para el desarrollo del docente, Marshall Welch y Star Plaxton-Moore ofrecen una introducción accessible, a la vez que exhaustiva, a las becas en el marco de la participación comunitaria. Las tres secciones principales del libro presentan una secuencia de desarrollo que puede ayudar al docente a adquirir las competencias eseciales del académico comprometido con la comunidad. Este libro de texto, pensado originalmente para programas de capacitación docente, beneficiará no sólo a nuevos académicos sino también a los experimentados, por su visión casi enciclopédica de la historia, los fundamentos teóricos y las mejores prácticas del compromiso entre la universidad y la comunidad.

Palabras clave: capacitación docente, aprendizaje en servicio y participación comunitaria, enseñanza y aprendizaje

Editors' Note: Translation by Yamilet Hernandez Department of English and Foreign Languages Barry University, USA

As institutions of higher education look to expand and improve their community engagement efforts, effective faculty development has arisen as a key factor in determining how successful a university's engagement endeavors will be. More than 25 years ago, Mary Walshok described the need for universities to have these types of "enabling mechanisms" that would support faculty who hoped to connect their research, teaching, and service to issues of social concern (Walshok, 1995). Holland and Zlotkowski, shortly after, described various models of faculty development in the field of service-learning and community engagement (SLCE) (Holland, 1999; Zlotkowski, 1998). In their influential essay, Hollander, Saltmarsh, and Zlotkowski named faculty development programs as one of 10 key "indicators of engagement" that were essential to universities seeking to institutionalize effective, reciprocal, and transformative partnerships with their wider communities (Hollander et al., 2001). More recently, Berkey et al. (2018) have gathered the scholarship to date on faculty development in university-community engagement, examining the theoretical foundations, predominant models, and trajectories in the field. 
In The Craft of Community-Engaged Teaching and Learning: A Guide for Faculty Development, seasoned SCLE scholar-practitioners Marshall Welch and Star Plaxton-Moore take up the mantle of this evolving, essential topic. Having already produced a rich literature review, as well as a robust theoretical work in the area (Welch \& Plaxton-Moore, 2017, 2018), the authors approach this text in a more practical vein. In The Craft of Community-Engaged Teaching and Learning, they provide a functional introduction to engaged scholarship, intended for use by individuals or groups and ideally as part of a campus-based faculty development program. The book is written in a conversational manner, highly accessible to those with a limited background in community engagement. At the same time, it roots itself in the historical lineages of community engagement and reflects the best of contemporary scholarship. Although such an expansive undertaking will naturally have its limitations, the overall product is highly effective, providing a useful resource for new and experienced engaged scholars alike.

The Craft of Community-Engaged Teaching and Learning is divided into three major sections, aimed at providing a developmental sequence that can help faculty establish core competencies of the communityengaged scholar as defined in the field (Axtell, 2012; Blanchard et al., 2009). In each section, Welch and Plaxton-Moore provide key theoretical grounding, useful tools, and areas for future exploration. An online workbook accompanies the text and is meant to provoke reflection on the material being covered throughout the work. Furthermore, there are helpful QR codes embedded in each chapter that can be scanned by any smartphone, and that connect the reader to useful videos by leaders in the field. Each chapter concludes with a section titled "Honing the Craft," which prompts the reader to integrate the material covered in the text into their own scholarship and community-engaged practice.

Part One of the text, "Laying the Foundations," explores the historical and theoretical foundations of community-engaged scholarship as it is understood today. In this section, the authors' aim is to facilitate the reader's movement beyond being an "instructor teaching a community-engaged course" toward being a "community-engaged scholar" (p. 5). Chapter One provides historical context, examining the original civic mission of universities in the United States, the shift toward "pure research" in the early half of the 20th century, and Boyer's call for a "reimagined" scholarship of engagement. The opening chapter also looks at contemporary efforts to develop university-wide engagement practices that are reciprocal with the community, involve a collaborative epistemological approach, and engage all three modes of the traditional academic triad (research, teaching, and service). Chapter Two provides theoretical background on the civic dimensions of, and developmental approaches to, transformative community-engaged learning (including Dewey, Kolb, Fry, Schon, and Mezirow). The chapter goes on to consider theory-based, feminist-informed critical race theory and social development-informed approaches to engagement, beginning with Freire and including Addams, hooks, Crenshaw, Vygotsky, and others. The authors suggest a summative, triadic model of community-engaged learning that requires a new epistemic stance ("head"), that provokes transformative critical reflection ("heart"), and that leads to a reorientation of the participants" actions in the world ("hands"). Chapter Three explores various modalities of community-engaged pedagogy (civic development-focused, solidarity-focused, research-aimed, etc.), as well as several social justice frameworks for engagement (critical service-learning, liberating service-learning, decolonizing service-learning, etc.). The final two chapters of Part One focus on problematizing the question of "community" in community engagement (including a discussion of positionality and the power of the academic), as well as the need for intercultural competence, cultural humility, and the development of critical consciousness through engagement efforts.

Part Two of the text moves from the theoretical to the practical, walking the reader through a process by which they can take the theoretical grounding of Part One and put it into practice by developing their own community-engaged course. The authors provide guidance on establishing course objectives - both "explicit," disciplinary objectives and "ancillary," civic and community outcome objectives. They then describe how one might develop a clear, mutually beneficial partnership with a community-based organization, as well as ways to organize the engagement process with the partner throughout a semester. Part Two continues with a helpful chapter focused on the theoretical foundations and practical tools for facilitating reflection in the community engagement process. Finally, in Chapter 10, the reader is offered a basic introduction to assessment (and its concomitant, but distinct, process of evaluation) aimed at 
evaluating the effectiveness of the course in meeting both the explicit and ancillary objectives set in place during the first stage of developing the class.

Part Three of the text, "Advancing the Craft," rounds out the book by moving beyond the development, implementation, and assessment of an individual course to consider the development of the faculty member as an "engaged scholar." Chapter 11 discusses the broad theme of scholarship. In it, the authors revisit Boyer's "Scholarship of Engagement," consider participatory approaches to scholarship production, and suggest more inclusive definitions of what constitutes "valid" dissemination of learning from communityengaged processes. Chapters 12 offers practical advice for those preparing for performance reviews, focusing on the importance of defining engaged scholarship for those conducting reviews, and establishing the scholarly value of such work for those who might not be as familiar with (or hold much esteem for) community-engaged approaches. Chapter 13 discusses the topic of mentoring (and coaching) faculty as they begin community-engaged work for the first time. Chapter 14, meanwhile, explores strategies by which faculty can influence their universities to institutionalize engagement more effectively on their campuses. The book ends with two chapters that bring the reader to reflect on their own, long-term role in civic engagement, as both a "citizen scholar" and a "reflective practitioner," ever working to assess, reassess, reimagine, and improve their community engagement efforts.

Welch and Plaxon-Moore have taken on a dizzying array of topics in the text, managing to sequence them in a clear, effective manner for those looking to develop their identity and practice as engaged scholars. While they have succeeded remarkably in this effort, there are a few weaknesses that come with such an approach. First, such a wide overview necessarily means that even key topics in the field - such as the theoretical foundations of Dewey and Freire, or critical approaches by Mitchell and Cruz-are afforded only a few short paragraphs. Furthermore, the sections on assessment and evaluation, while effective, afford only a brief introduction to what good assessment could look like. While the seasoned engaged scholar will see that these overviews are meant to be only simplified introductions, readers not as familiar with the material might see them as authoritative. This could, in turn, lead to situations where the practices proposed (such as those in the assessment section) could potentially be seen as best-practice goals, rather than simply starting points in community-engaged assessment efforts.

Similarly, by addressing the text to individual faculty members in formation, the authors gloss over broader institutional factors that are essential to effective university-community engagement. This is perhaps most apparent in the section on assessing community outcomes in engagement. Whereas the authors make clear the need for a long-term process of relationship building with community partners, the majority of the text frames community engagement as happening at the individual course level and over the timeframe of a single semester.

Scholars such as Mary Beckman have challenged such approaches as insufficient, and even potentially harmful. Beckman has argued that if true community impact is desired in university-community partnerships the unit of analysis must move from faculty member and community organization to institution and community-identified need (Beckman et al., 2011; Beckman \& Wood, 2016). In other words, true community impact will never be possible in an individual semester, and most community change efforts cannot be sufficiently resourced by an individual faculty member alone. Instead, Beckman has suggested, long-term, interdisciplinary university-community partnerships are essential. If any true, long-term community impact is to be achieved, a variety of disciplinary resources and a variety of modalities of engagement will be necessary in the context of long-term partnership and commitment.

Welch and Plaxton-Moore, it should be noted, are not unaware of this. They mention the possibility of long-term models in their section on place-based initiatives (p. 212). They also suggest ways for supporting university-wide, institutionalized engagement in their section on institutional change (Chapter 14). Nonetheless, the overall thrust of the text is aimed at the individual faculty member, and the development of semester-long, course-based engagement with community partners. Such models may provide specific short-term "outputs" for community organizations but rarely will be able to facilitate the long-term community impact that universities purportedly seek to achieve - and, in worst cases, may lead to instability for community partners when faculty and course schedules shift. 
These weaknesses in the text, however, are very minor. Overall, the book provides a well-executed, virtually encyclopedic introduction to the theory and practice of university-community engagement. While it is clearly intended as a formation tool for faculty new to such work, I believe that even well-seasoned community-engaged scholars will find it useful for revisiting core themes in the field, with each section referencing the essential scholars and primary documents relevant to each area. We all-no matter our level of experience - owe Welch and Plaxton-Moore gratitude for their well-written, summative addition to the field.

\section{References}

Axtell, S. (2012). Creating a community-engaged scholarship (CES) faculty development program. University of Minnesota Digital Conservancy, http://hdl.handle.net/11299/213716

Beckman, M., \& Long, J. (Eds.). (2016). Community-based research: Teaching for community impact. Stylus.

Beckman, M., Penney, N., \& Cockburn, B. (2011). Maximizing the impact of community-based research. Journal of Higher Education Outreach \& Engagement, 15(2), 83-103.

Beckman, M., \& Wood, D. (2016). The role of community-based research in achieving community impact. In M. Beckman \& J. Long (Eds.), Community-based research: Teaching for community impact (pp. 33-49). Stylus.

Berkey, B., Meixner, C., Green, P. M., \& Eddins, E. A. (Eds.). (2018). Reconceptualizing faculty development in service-learning/community engagement: Exploring intersections, frameworks, and models of practice. Stylus.

Blanchard, L. W., Hanssmann, C., Strauss, R. P., Belliard, J. C., Krichbaum, K., Waters, E., \& Seifer, S. D. (2009). Models for faculty development: What does it take to be a community-engaged scholar? Metropolitan Universities, 20(2), 47-65.

Holland, B. (1999). Factors and strategies that influence faculty involvement in public service. Journal of Public Service and Outreach, 4(1), 37-43.

Hollander, E., Saltmarsh, J., \& Zlotkowski, E. (2001). Indicators of engagement. In L. A. Simon, M. Kenny, K. Brabeck, \& R. M. Lerner (Eds.), Learning to serve: Promoting civil society through service-learning. Springer.

Walshok, M. (1995). Knowledge without boundaries: What America's research universities can do for the economy, the workplace, and the community. Jossey-Bass.

Welch, M., \& Plaxton-Moore, S. (2017). Faculty development for advancing community engagement in higher education: Current trends and future directions. Journal of Higher Education Outreach and Engagement, 21(2), 131166.

Welch, M., \& Plaxton-Moore, S. (2018). A holistic framework for educational professional development in community engagement. In B. Berkey, C. Meixner, P. M. Green, \& E. A. Eddins (Eds.), Reconceptualizing faculty development in service-learning/community engagement: Exploring intersections, frameworks, and models of practice (pp. 27-58). Stylus.

Zlotkowski, E. (1998). Successful service-learning programs: New models of excellence in higher education. Anker.

\footnotetext{
About the Author

Anthony Vinciguerra is the former coordinator of the Center for Community Engagement at St. Thomas University (Miami, FL, USA) and currently a doctoral student in theology and education at Boston College (Boston, MA, USA).

Correspondence concerning this article should be addressed to Anthony Vinciguerra at anthony.vinciguerra@bc.edu.
} 